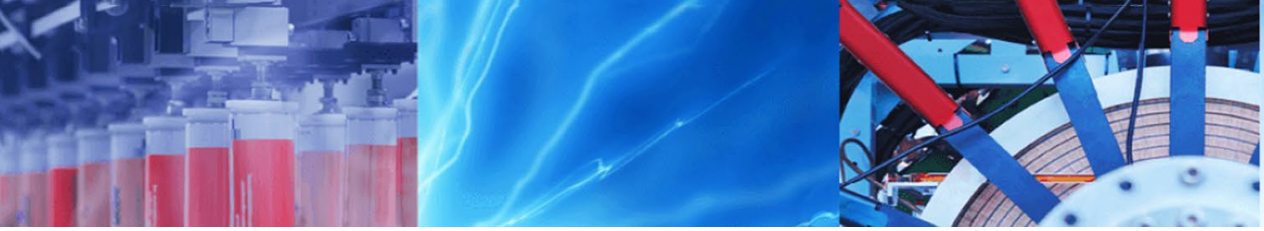

Research Article

\title{
Mesofauna as an indicator of agroecosystem stability: degree of artificialization effect on land uses in Azul district, Argentina
}

\author{
M. T. Cassani ${ }^{1}$ D $\cdot$ M. L. Sabatté ${ }^{1} \cdot$ A. González Arzac $^{2}$ - M. J. Massobrio ${ }^{1}$ (D)
}

Received: 16 November 2019 / Accepted: 28 January 2020 / Published online: 3 February 2020

(c) Springer Nature Switzerland AG 2020

\begin{abstract}
Chronic anthropogenic stress agents include the different tillage systems, which usually influence the population metrics of cryptofauna communities. Among them, the edaphic mesofauna is sensitive to natural and anthropogenic disturbances of the environment, producing changes in its specific composition and abundance. This allows us to select it as an indicator of disturbances generated in the stability of the ecosystem by land use. Taking these into consideration, the objective of this work was to study the effect of the degree of artificialization in land use on the stability of the agroecosystem through mesofauna. The study area was located in an environment of peripheral hills of the district of Azul. Four sites were selected in similar geoenvironments, with different degrees of artificialization of land use. Edaphic parameters were analysed in each site, and mesofauna individuals were identified through keys for population analysis. Mesofauna population metrics were analysed. Biological indicators were applied. Through mesofauna it was possible to differentiate sites with different degrees of artificialization by land use. Biological indicators allowed us to determine the stability of agroecosystems.
\end{abstract}

Keywords Acari · Collembola · Biological indicators · Land use history · emergent property

\section{Introduction}

In recent years, there has been growing concern about the types of use and management of the edaphic ecosystem that contribute to human well-being. Although soil quality is conceptualized as the main link between strategies for management practices and the execution of the main objectives for achieving sustainable agriculture, it should not be overlooked in terms of optimal soil functioning in the ecosystem [12]. Researchers in soil conservation and management have made great progress in describing and understanding the complex biological, biophysical and biochemical interactions of soil $[8,9]$. These interactions provide the soil as habitat for the food webs of edaphic cryptofauna and vegetation. In agricultural ecosystems, the different tillage systems are considered as chronic stress agents which affect the population metrics of the soil fauna communities [23].

The use of agricultural ecosystems should be analysed in the context of their environmental fragility. It affects the sustained harvesting of the ecosystem, driving it to nonoptimal states from the human point of view, in a destructive trend known as ecosystem disease [18]. The landscape is altered by anthropogenic activities and at the same time affects the quality of life. Physical processes (meteorization, adsorption, desorption, water and air exchange, etc.), chemical processes (ion exchange, dissolution, precipitation, etc.) and biological processes (bioturbation decomposition, root growth, etc.) all take place at characteristic spatial and temporal scales and sometimes involve a

$\triangle$ M. T. Cassani, mcassani@agro.uba.ar| 'Faculty of Agronomy, Chair of Soil Management and Conservation, University of Buenos Aires, Avenida San Martín 4453, Buenos Aires C1417DSE, Argentina. ${ }^{2}$ Faculty of Agronomy, Institute of Physiological and Ecological Research Linked To Agriculture (IFEVA-CONICET), University of Buenos Aires, Avenida San Martín 4453, Buenos Aires C1417DSE, Argentina. 
certain range of scales with certain invariant qualities in all of them. The edaphic ecosystem is a historical result, and one could say that it is an evolutive result. In this sense, it can be assumed that it has been submitted to a selective process ("sensu lato") that has produced systems with a high efficiency in the processing and dissipation of the external energy they receive. In this way, anthropogenic energy such as different tillage systems is considered artificialization in land use. Taking into account these considerations, stability is an emerging property of each system, which would indicate in summarized form what condition it is in relation to the external anthropic energy (artificialization) it receives and its capacity to metabolize it, maintain control over its condition and persist [19].

Traditionally, agricultural production systems have been evaluated through the concept of quality, where chemical, physical and biological indicators have been used. In the Mesofauna, mite subclasses (Acari) and the springtail subclass (Collembola) are the most important biological indicators of ecosystem condition [25] and soil quality $[2,3]$. Furthermore, the spatial distribution of mesofauna organisms is closely related to the increasing pressure on agroecosystems, as a result of which some of the edaphic parameters, such as organic matter [13-15], promote spatial heterogeneity and the activity of mesofauna organisms at different scales [8].

In the 1990s, an advance was observed in the evaluation of ecosystems based on the edaphic mesofauna. Andrés [1] and Behan-Pelletier [5] highlighted the role of the Oribatid (Mites) as biological indicators of moisture and organic matter content in forest ecosystems, as well as in forest plantations and agroecosystems. At the same time, the growing knowledge of edaphic cryptofauna allowed the development of biological indicators that use mesofauna as an indicator of soil quality [2,3]. Andrés [1] proposed the relationship between Mites: Oribatid/Prostigmata and Mateos [20] presented the relationship Acari/Colembolla, to determine the degree of stability in different land use systems.

\subsection{Objectives}

Taking into consideration previous statements, the general objective of this work was: study the effect of the degree of artificialization in the land use on the stability of the agroecosystem through mesofauna in hilly environments of the district of Azul, Province of Buenos Aires, Argentina.

The specific objectives were:

Analyse different soil organic fractions to characterize the sites under study.

Describe and compare the mesofauna in the sites under study.

Apply biological indicators to estimate stability in the sites under study.

\section{Materials and methods}

\subsection{Selection and characterization of study sites}

The district of Azul is located in the middle of the Province of Buenos Aires, in the Pampas Serrana region $\left(36.13^{\circ} 37.27^{\circ} \mathrm{S}\right.$ and $59.08^{\circ} 60.12^{\circ} \mathrm{W}$ ) (Fig. 1). According to the classification of Köppen, the district of Azul has a humid temperate climate with oceanic influence, mild
Fig. 1 Location of the study area within the hilly environment in the district of Azul (Province of Buenos Aires)

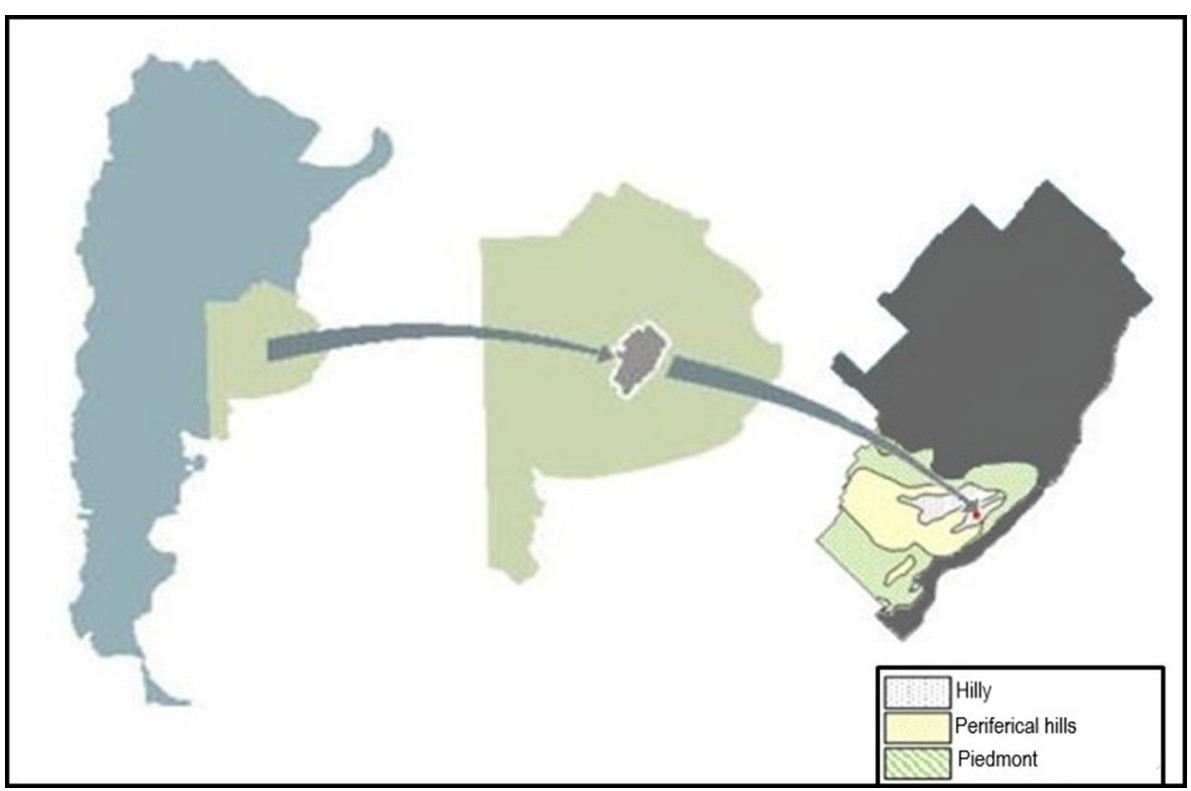


winters, short and cool summers and has all wet seasons. It has an average of $915 \mathrm{~mm}$ of precipitation and average temperatures of $21.8^{\circ} \mathrm{C}$ for the month of January and $7{ }^{\circ} \mathrm{C}$ for the month of July and an annual average of $14^{\circ} \mathrm{C}$ [24].

The study area was located in the hilly environment of Azul district and corresponded to 3760-22-2, soil map of the Argentine Republic [15].

We proceeded to select four study sites in a transect corresponding to the same level curve at 240 of altitude.

The selected sites are listed below (Table 1).

The sites represent an increasing gradient in the artificialization degree associated with different tillage systems used over the past 25 years, from non-agricultural site "Closure" (less artificialized) to site 4 with different types of tillage (the most artificialized). The soil present in the study sites was Mar Del Plata serie, Tipic Argiudol (Soil Taxonomy 2006) [15].

\subsection{Particulate organic matter (POM), organic carbon $(\mathrm{OC})$ and loss of ignition (LOI)}

The field correlations of the series described for the environment of peripheral hills were carried out with soil auger sampling at a depth of $0.8 \mathrm{~m}$.

In the field-selected sites, soil samples were collected of five random subsamples at a depth of $0-10 \mathrm{~cm}$. These were conditioned and transported to the laboratory, where they were air-dried and then sieved using a 2-mm-diameter mesh and stored in plastic bags for further analysis. Sampling took place in May 2017, January and September 2018.

Organic matter was characterized through different fractions: particulate organic matter (\%POM > $50 \mu)$, organic carbon (\%OC) and loss of ignition (\%LOI).

The parameters of the soil samples studied were determined by standardized methods $[7,21,22]$ which are detailed below:

- Particulate organic matter $(\% \mathrm{POM}>50 \mu)$ allows to discretize different management practices in shorter time spaces $[13,14]$;

- Organic carbon (\%OC), LECO model CR12. It is a very reliable method, and it allows to separate different sites against different management practices [13];
- Loss of ignition (\%LOI): organic matter by calcination. It allows to separate different sites against different management practices [15].

\subsection{Mesofauna and biological indicators}

In order to identify and classify the mesofauna in the experimental sites, two random samples were taken from each selected site, with 5-cm-diameter and 7-cmdeep punch with the accompanying stubble [17]. Sampling was carried out during January, March, September and December of 2018.

The samples were separated from the different components of the fauna using modified Berlese funnels [6]. The specimens were fixed in $70 \%$ alcohol for their conservation and later identified by keys [11] up to the suborder level, and the count of individuals was carried out. Then, with the aim of determining the agroecosystem stability we used the following biological indicators:

- The Oribatid/Prostigmata relationship [1] (values $\geq 1$ are stable agroecosystems, values $<1$ unstable agroecosystems).

- The Acari/Colembolla relationship [20] (values $\leq 1$ are stable agroecosystems, values $>1$ are unstable agroecosystems).

\subsection{Statistical processing of information}

For the analysis of \%POM, \%OC and \%LOI for the four sites under study, mixed models were used. When significant differences were found, the LSD Fisher test was applied for mean comparison $(p \leq 0.05)$.

Responses of mesofauna suborders to sites were evaluated by discriminant multivariate analysis [17]. Differences between the densities of the suborders and the different treatments were calculated using Kruskal-Wallis test.

The statistical analyses and discriminant analysis graphs were performed using the Infostat ${ }^{\circledR}$ software interface with $R$ [10]. The graphs of individual $\mathrm{m}^{-2}$ were made using GraphPad Prism ${ }^{\circledR}$ software.

Table 1 The different sites selected and the characteristics of the history of land use of each one

\begin{tabular}{ll}
\hline Site & Characteristic \\
\hline Non-agriculture site & Closure of 25 years. Closed for research, where animal access and sowing were prevented. It has a naturalized prairie \\
2 & No-tillage agriculture for 25 years \\
3 & Tillage with moldboard plough for 10 years and then No-tillage agriculture until today, 15 years \\
4 & Different types of tillage from 25 years ago to the present day (moldboard plough, disc plough and no-tillage)
\end{tabular}




\section{Results}

\subsection{Particulate organic matter (POM), organic carbon (OC) and loss of ignition (LOI)}

There were statistically significant differences of the variable \%POM in non-agricultural site and site 2 with respect to sites 3 and 4 . They presented the highest and lowest values found for the variable, respectively. Non-agricultural site and site 2 did not differ from each other, neither did sites 3 and 4 . The \%OC variable was effective in separating between sites. Non-agricultural site had the highest $\% \mathrm{OC}$ values, differing significantly from the rest. It is followed by site 2 , site 3 and site 4, respectively, in decreasing values. All the sites showed significant differences between them. The \%LOI variable also separated different sites. Non-agricultural site presented the highest \%LOI values, differing statistically from the rest. Site 2 followed in decreasing value to non-agricultural site, differing statistically from the rest. Sites 3 and 4 presented the lowest values and both differed from the rest, but not between them (Table 2).

\subsection{Mesofauna and biological indicators analysis}

Non-agricultural site presented the highest values of mites and springtails per $\mathrm{m}^{-2}$. No significant differences were found for acari variable (Fig. 2a), and a trend was observed where non-agricultural site presented the highest values, followed by site 4 , and then, by sites 2 and 3 with similar values. In collembola, on the other hand, significant differences were found. Non-agricultural site differed significantly of individual $\mathrm{m}^{-2}$ from the rest of the sites $(2,3$ and 4). Sites 2, 3 and 4 presented similar values and were not statistically different (Fig. 2b).

In the analysis of the number of individuals of each suborder between the different sites, it was observed that Oribatid (Fig. 3a) presented the highest number of individuals in non-agricultural site, being statistically different from the rest. Sites 2 and 3 presented the lowest values, being statistically equal between them. Site 4 presented intermediate values, being statistically equal to non-agricultural site as well as to sites 2 and 3 .

For Astigmata, no significant differences between sites were found, but a trend of higher individual $\mathrm{m}^{-2}$ was observed at non-agricultural site (Fig. 3b). In Prostigmata, no differences between sites were observed, but a trend of higher values was observed in sites 3 and 4 (Fig. 3c). In Mesostigmata, no significant differences were found between the sites. In all cases, very low values of individual $\mathrm{m}^{-2}$ were observed (Fig. $3 \mathrm{~d}$ ).

Only significant differences were found for the suborder Symphypleona (Fig. 4c). Non-agricultural site showed the highest value and significant differences with the rest. Sites 2 and 3 presented intermediate values between sites 1 and 4 , not differing significantly from both. Site 4 had the lowest values, differing significantly from non-agricultural site.

Figure 4 indicates that no significant differences were found between sites in relation to the suborders
Table $2 \%$ POM (particulate organic matter), \%OC (organic carbon), \%LOI (loss of ignition) for the four sites analysed. The different letters indicate significant differences between the sites $(p \leq 0.05)$

Fig. 2 Number of individual $\mathrm{m}^{-2}$ present at each site. a acari, b collembola. The different letters indicate significant differences $(p \leq 0.05)$

\begin{tabular}{llllllllll}
\hline Site & \%POM & SE & $\begin{array}{l}\text { Significant } \\
\text { difference }\end{array}$ & \%OC & SE & $\begin{array}{l}\text { Significant } \\
\text { difference }\end{array}$ & \%LOI & SE & $\begin{array}{l}\text { Significant } \\
\text { difference }\end{array}$ \\
\hline 1 & 2.1 & 0.37 & $\mathrm{a}$ & 4.93 & 0.08 & $\mathrm{a}$ & 10.92 & 0.31 & $\mathrm{a}$ \\
2 & 1.69 & 0.37 & $\mathrm{a}$ & 3.71 & 0.08 & $\mathrm{~b}$ & 9.25 & 0.31 & $\mathrm{~b}$ \\
3 & 0.92 & 0.37 & $\mathrm{~b}$ & 3.34 & 0.08 & $\mathrm{c}$ & 8.39 & 0.31 & $\mathrm{c}$ \\
4 & 0.41 & 0.37 & $\mathrm{~b}$ & 2.64 & 0.08 & $\mathrm{~d}$ & 7.63 & 0.31 & $\mathrm{c}$ \\
\hline
\end{tabular}
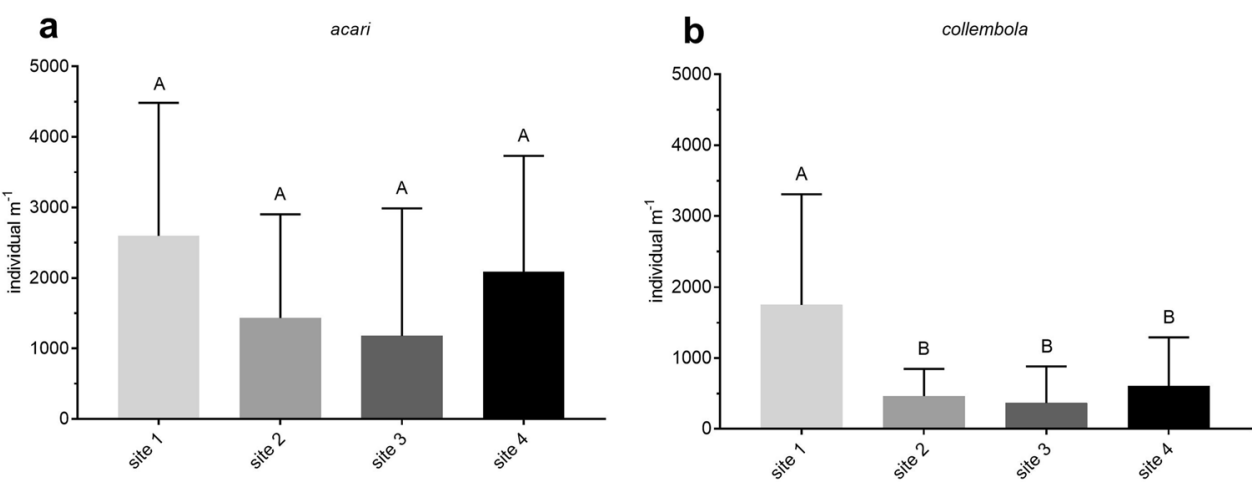
Fig. 3 Number of individual $\mathrm{m}^{-2}$ of each acari suborder present at each site. Oribatid (a), Astigmata (b), Prostigmata (c) and Mesostigmata (d). The different letters indicate significant differences $(p \leq 0.05)$
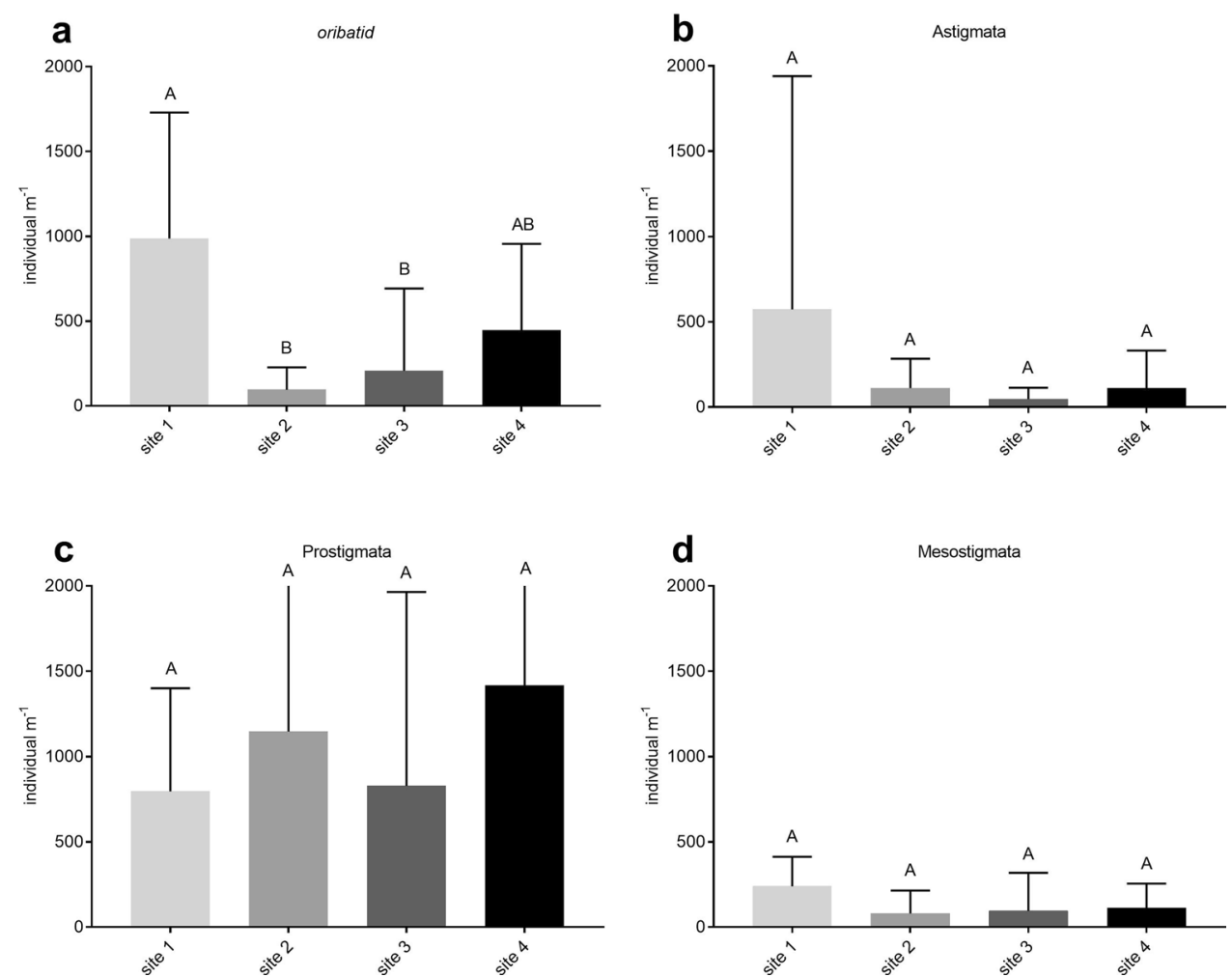

Fig. 4 Individual $\mathrm{m}^{-2}$ of each suborder of collembola present at each site. Poduromorph (a), Entonomorph (b) and Symphypleone (c). The different letters indicate significant differences $(p \leq 0.05)$
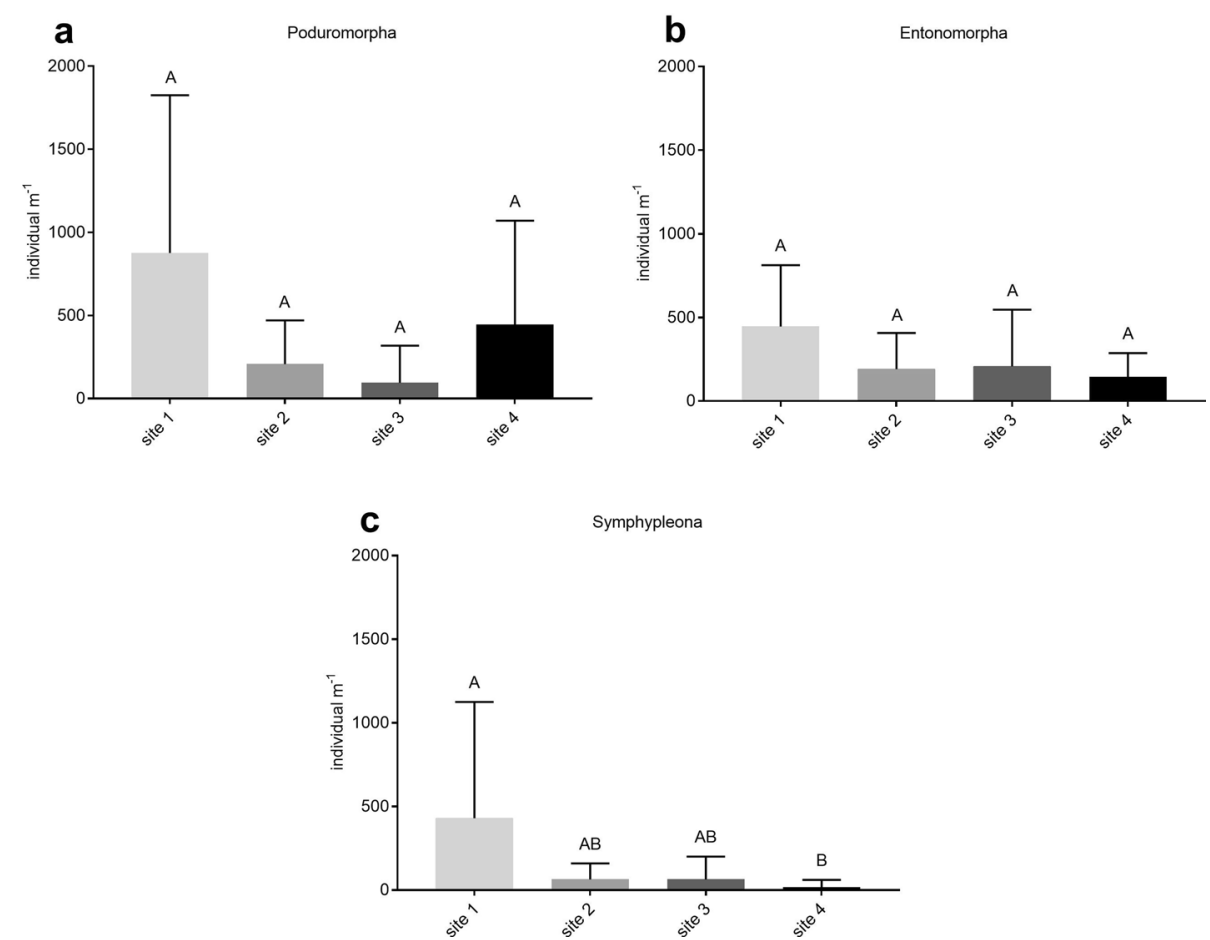

Poduromorpha and Entonomorpha. A trend of higher values of individual $\mathrm{m}^{-2}$ was observed in non-agricultural site.

In order to discriminate the effect of sites on mesofauna, a discriminant analysis was carried out using the different mesofauna suborders presented at each site (Fig. 5).
This analysis gave significant statistical differences. Axes 1 and 2 explained $99 \%$ of the variation found $(77 \%$ axis 1 and $22 \%$ axis 2 ). It is clearly observed that the points corresponding to non-agricultural site, the lowest level of artificialization, were distributed to the right of line 0 
Fig. 5 discriminant mesofauna analysis for the sites under study. Being 1 closure, 2, 3 and 4 sites with increasing level of artificialization

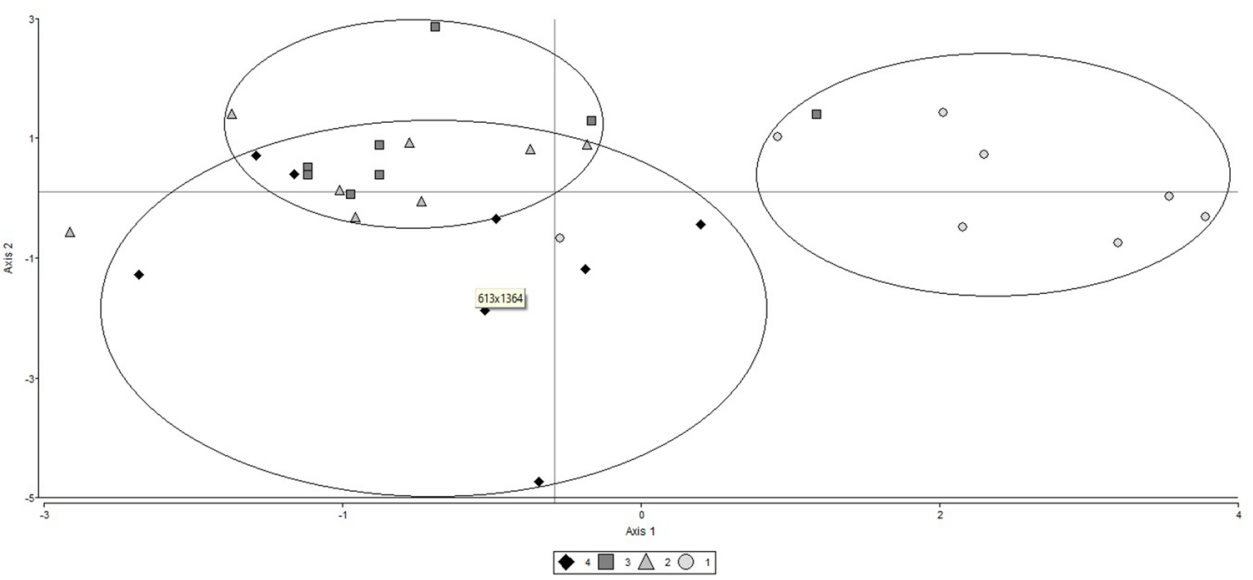

of canonical axis 1 (the one that explained most) and the points corresponding to the other sites, to the left of line 0 . This indicated that the non-agricultural site was indeed different from the rest of the agricultural sites.

On the other hand, sites 2 and 3 had a very similar distribution, and their points were located above axis 0 of canonical axis 2 , separating them from the points corresponding to site 4 . Within agricultural sites, sites 2 and 3 resembled each other and were separated from site 4 . In canonical axis 1, the suborders oribatid, prostigmata and entonomorpha were the components of the axis that most explained it. In turn, in canonical axis 2, symphypleona, astigmata and mesostigmata were the suborders that most explained it.

This analysis was congruent with those analysed for the density of individual $\mathrm{m}^{-2}$ where non-agricultural site differed from the rest of the agricultural sites. Agricultural sites 2 and 3 were similar, and site 4 was different. Therefore, canonical axis 1 mainly separated non-agricultural site, the closure, from the rest of the agricultural sites, and the axis 2 separated the agricultural sites from each other.

To identify the agroecosystem stability, biological indicators were applied. The Oribatid/Prostigmata indicator (Fig. 6a) showed that non-agricultural site reached values greater than "1," the rest of the (agricultural) sites had values below "1." The indicator acari/collembola (Fig. 6b) showed that agricultural sites 2, 3 and 4 reached values of "3," and non-agricultural site a value slightly higher than 1 .

\section{Discussion}

In this study, only the soil parameter \%OC was the best to differentiate and accurately indicated contrasts between sites, confirming a gradient of artificialization by land use, from non-agricultural site to site 4 . In addition, similar results were obtained for Eyherabide et al. [15], for the same region. However, the same author affirmed that \%LOI

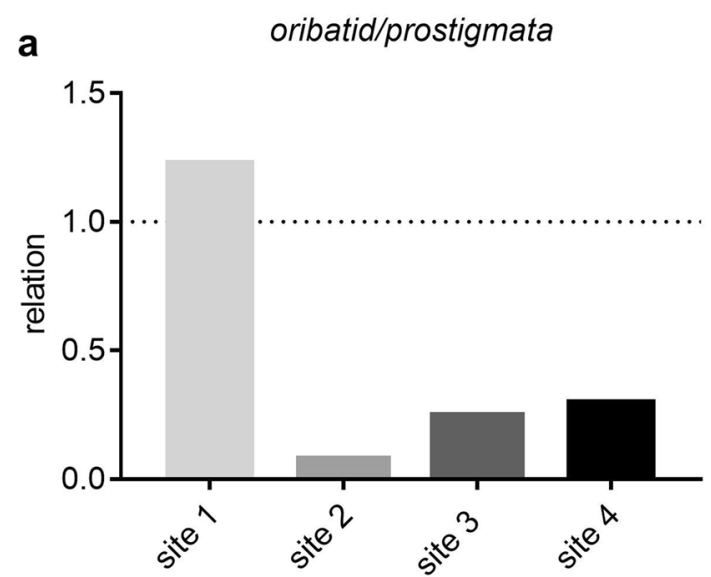

b acari/collembola

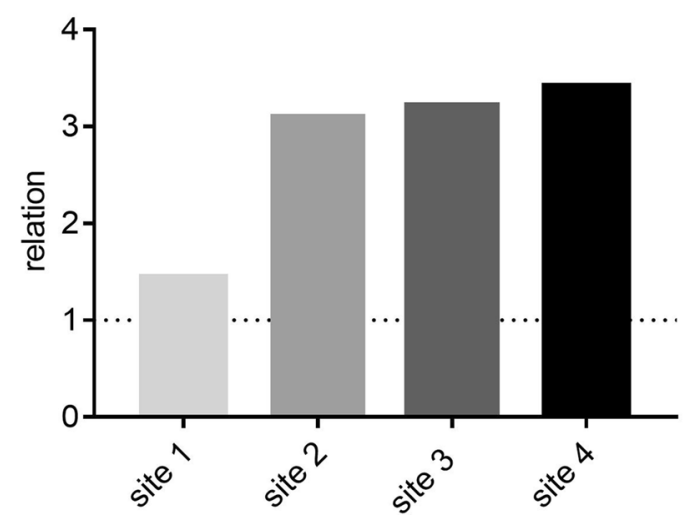

Fig. 6 stability indicators for each study site. a oribatid/prostigmata and $\mathbf{b}$ acari/collembola

was also effective as \%OC. This is not consistent with our results, but \%LOI was effective in separating non-agricultural sites from agricultural sites. Results for \%POM were different to \%OC and \%LOI. This parameter only separates the non-agricultural site and the less artificialized 
site from the sites 3 and site 4 both with higher degree of artificialization. Close results were found by Eiza et al. [14] where \%POM was effective to separate different soil management practices in the first few centimetres for typic argiudol in Pampa Serrana region. Furthermore, we found that \%POM and \%OC were lower in agricultural soils than closure. These results were similar to those obtained by Duval et al. [13]

In concordance with a gradient of artificialization by land use confirmed by \%OC analysis, the results of mesofauna population metrics revealed differences in sensitivity to human disturbances between sites, in agreement with Pankhurst et al. [23] and Cassani et al. [8]. We found large differences between non-agriculture site and agricultural sites (2, 3 and 4). Bedano et al. [4], in west Pampa Húmeda region, Argentina, found differences in mite's population metrics between non-agriculture sites and anthropized sites. These results were in accordance with ours. Actually, according to Behan-Pelletier [5], oribatid mites are the most susceptible to management practices; therefore, their relative abundance in less anthropized sites is greater, and these statements were observed in the nonagriculture site. Furthermore, Sousa et al. [29] in Portugal observed for colembolla, differences in population metric in sites with higher degrees of artificialization by land use, showing that land use influences the metric populations of springtails. Alike results were found in our investigation, where there were more individuals of colembolla in non-agriculture site vs. agricultural sites. Moreover, the abundance of symphypleona in non-agriculture site was the most abundant of all sites, being less abundant in sites 3 and 4, both with the highest degree of artificialization by land use, in concordance as reported by Sousa et al. [29]. In addition, Socarrás and Izquierdo [27] claimed that grassland areas are distinguished by a high dominance of microarthropods responsible for the decomposition of organic matter (stability indicators) and a sharp drop in the abundance of the rest of the groups (disturbance indicators) of the soil environment. It is therefore suggested that oribatids and colembolla are groups that effectively indicate stability in the system. Besides, according to Socarrás [28], springtails and mesostigmata (cohort gamasina) are the most affected groups by agronomical management practices in grasslands in Cuba.

In line with Socarrás and Izquierdo [27], and Socarrás [28], mites (especially oribatids and mesostigmata) and colembolla (principally symphypleona) are considerate good indicators of soil stability and fertility.

Not to mention, the discriminant analysis gave information that complemented to the density of individual $\mathrm{m}^{-2}$. This analysis confirmed many of the differences found between the suborders of mites and springtails respect to the sites under study, which in this case would be the treatments of this experiment. It was possible to discriminate between non-agricultural site from the rest of the experimental sites. Same results found by Bedano et al. [3] in their study was that a canonical analysis separated the natural environment (non-agricultural site with a closure of 30 years) from the rest of the agricultural sites, in the centre, east of Cordoba province and north of Buenos Aires province.

The application of biological indicators of stability resulted in a great difference of non-agricultural site with the rest of the sites. In both indicators used, this difference was observed. In acari/collembola indicator, the agriculture sites were in a state of imbalance or greater disturbance, being unstable systems, in contrast to nonagricultural site (stable systems). Similar results were found by Socarrás and Rodríguez [26], for disturbed sites, where in agroecosystems recultivated with pinus cubensis, in a former mining zone, they had a very high Acari/Collembola ratio, even after 16 years of reforestation. The indicator Oribatida/Prostigmata showed same results than Acari/Collembola indicator. There was a dominance of Prostigamata in agricultural sites, an indicator group of oligotrophy and aridity, where the degree of imbalance of the communities is unreversible, therefore, unstable sites. In contrast, the non-agriculture site was stable. Same results were obtained by Bedano et al. [4], where they found values of great balance (stable system) in a 40-year closure and in cattle sites. Likewise, Socarrás and Izquierdo [25] found similar results, where in pasture sites the values were "stable," and in agricultural sites, "unstables."

Stability of the agroecosystem is the result of the landscape components interaction. This study gave us information to monitor artificialization in land use. Moreover, stability variable can be incorporated into the building of more sustainable land management models.

\section{Conclusions}

The different fractions of organic matter analysed (\%POM, $\% O C, \%$ LOI) were useful to indicate differences between sites, but it was $\% \mathrm{OC}$ that allowed to accurately indicated contrasts between sites, confirming a gradient of artificialization by land use, from non-agricultural site to site 4 .

The stability of an agroecosystem considers the interaction of all the components of the landscape and allowed the study of the interfaces that compose it. For that reason, stability is an emerging property that is specific to each agroecosystem, where going to more stable systems would be the optimal in terms of energy. According to results, biological indicators allowed us to determine the stability of agroecosystems. In stable systems, with a low degree of artificialization, the populations of oribatid and 
collembola increase, suborders that contribute to the stability. In the other hand, in unstable systems, which receive more external energy from artificialization, the mesofauna was less. At the same time, the suborders of astigmata and prostigmata proliferated, indicating disturbances, aridity and oligotrophy.

Acknowledgements The authors acknowledge the assistance of Ing. Agr. Mailen Riveira Rubin for translate assistance.

Funding This study was funded by University of Buenos Aires, projects UBACyT Res. 20020170100612BA and 20020130100690BA.

\section{Compliance with ethical standards}

Conflict of interest The authors declare no conflict of interest

\section{References}

1. Andrés $P$ (1990) Descomposición de la materia orgánica en dos ecosistemas forestales del macizo del Montseny (Barcelona): papel de los ácaros oribátidos (Acarina, Oribatei). Doctoral Thesis. Universidad Autónoma de Barcelona

2. Bedano JC, Cantú MP, Doucet ME (2006) Soil springtails (Hexapoda: Collembola), symphylans and pauropods (Arthropoda: Myriapoda) under different management systems in agroecosystems of the subhumid Pampa (Argentina). Eur J Soil Biol 42(2):107-119. https://doi.org/10.1016/j.ejsobi.2005.11.004

3. Bedano JC, Cantú MP, Doucet ME (2006) Influence of three different land management practices on soil mite (Arachnida: Acari) densities in relation to a natural soil. Appl Soil Ecol 32(3):293-304. https://doi.org/10.1016/j.apsoil.2005.07.009

4. Bedano JC, Cantú MP, Doucet ME (2001) La utilización de ácaros edáficos como indicadores de calidad de suelos en agroecosistemas del centro de Argentina. Memorias. XV Congreso Latinoamericano de las Ciencias del Suelo. [CDROM]. Varadero, Cuba

5. Behan-Pelletier VM (1999) Oribatid mite biodiversity in agroecosystems: role for bioindication. Invertebrate Biodiversity as Bioindicators of Sustainable Landscapes. https://doi.org/10.1016/b9780-444-50019-9.50023-6

6. Berlese A. (1888). Acari Austro-americani quos collegit Aloysius Balzan. Manipulus primus. Species novas circiter quinquaginta complectens. En: Bolletino della societa Entomol Italiana, $n^{\circ} 20$ : págs. 171-222.

7. Cambardella CA, Elliot ET (1994) Carbon and nitrogen dynamics of soil organic matter fractions from cultivated grassland soils. Soil Sci Soc Am J 58:123-130

8. Cassani MT, Sabatté ML, Massobrio MJ (2016) Distribución espacial de la materia orgánica, elphyla mesofauna en siembra directa. Trabajo $n^{\circ} 227$. Libro de Resúmenes del XXV Congreso Argentino de las Ciencias del Suelo. Rio Cuarto, CBA. Pág. 308. ISBN: 978-987-688-173-9

9. Deleporte S, Tillier P (1999) Long-term effects of mineral amendments on soil fauna and humus in an acid beech forest floor. For Ecol Manage 118(1-3):245-252. https://doi.org/10.1016/s0378 -1127(98)00505-2

10. Di Rienzo JA, Casanoves F, Balzarini MG, Gonzalez L, Tablada M, Robledo CW, InfoStat versión (2018). Grupo InfoStat, FCA, Universidad Nacional de Córdoba, Argentina

11. Dindal D (ed) (1990) Soil biology guide. Wiley, New York

12. Doran JW, Parking TB (1996) Quantitative indicators of soil quality: a minimum data set. In: JW Doran, AJ Jones (ed) Methods for assessing soil quality. SSSA Spec. Publ. № 49. SSSA, Madison, WI, pp 25-37

SN Applied Sciences
13. Duval ME, Galantini JA, Martínez JM, Iglesias JO (2016) Comparación de índices de calidad de suelos agrícolas y naturales basados en el carbono orgánico. Revista Ciencia del suelo (argentina) 34(2):197-209

14. Eiza MJ, Fioriti N, Studdert GA, Echeverría HE (2005) Fracciones de carbono orgánico en la capa arable: efecto de los sistemas de cultivo y de la fertilización nitrogenada. Ci. Suelo (Argentina) 23(1):59-67

15. Eyherabide M, Saínz RH, Barbieri P, Echeverría HE (2014) Comparación de métodos para determinar carbono orgánico en suelo. Revista Ciencia del suelo (argentina) 32(1):13-19

16. INTA (National institute of agronomical technology, Argentina) (1970) Carta de Suelos de la República Argentina Hoja 3760-22-2 Pablo Acosta. ISSN 0327-781X.

17. Kautz T, Lopez-Fando C, Ellmer F (2006) Abundance and biodiversity of soil microarthropods as influenced by different types of organic manure in a long-term feld experiment in Central Spain. Appl Soil Ecol 33:278-285. https://doi.org/10.1016/j.apsoi I.2005.10.003

18. Manly B. F. J. (2001). Statistics for environmental science and management, Wyoming (USA).

19. Massobrio M (2004) Agroecosistemas, el paisaje y las tecnologías. In: Malacalza L (ed) Ecología y Ambiente. Capítulo IX. Instituto de Ecología de Luján, pp 174-177. ISBN 987-21270-0-X.

20. Massobrio M (2003) Comportamiento de un paisaje fluvial: Análisis de la dinámica del agua en el suelo de una microcuenca del norte de la Provincia de Buenos Aires (Argentina). Doctoral dissertation. University of Vigo, Spain.

21. Mateos E (1992) Colémbolos (Collembola:Insecta) edáficos de encinares de la Serra de l'Ova y de la Serra de Prades (Sierra prelitoral catalana). Efecto de los incendios forestales sobre estos artrópodos. Doctoral dissertation. University of Barcelona

22. Nelson DW and Sommers LE (1996) Total carbon, organic carbon and organic matter. In: Sparks DL, et al. (eds.), Methods of soil analysis. Part 3. SSSA and ASA, Madison, WI, pp 961-1010

23. Page AL (1982) Method of soil analysis. Part 2: agronomy series monograph No 9. ASA, Soil Sci. Soc. Am., Inc. Madison, Wisconsin, USA.

24. Pankhurst C, Double BM, Gupta VVSR (1997) Biological indicators of soil health. $C A B$ International, Wallingford

25. SMN (2018) National Meteorological Service (Argentina). https:// www.smn.gob.ar/

26. Socarrás A, Izquierdo I (2014) Evaluación de sistemas agroecológicos mediante indicadores biológicos de la calidad del suelo: mesofauna edáfica. Pastos y Forrajes, Vol. 37, No. 1, enero-marzo, 47-54. ISSN 0864-0394

27. Socarrás A, Rodriguez M (2005) Utilizacion de la mesofauna como indicador biológico en áreas recultivadas con pinus cubensis en la zona minera de Moa, Holguín Cuba. ISBN 952-250-156-4.

28. Socarrás Rivero A, Izquierdo Brito I (2016) Variación de los componentes de la mesofauna edáfica en una finca con manejo agroecológico. Pastos y forrajes, Vol. 39, N¹, enero-marzo, 41-48, 2016. ISSN 0864-0394 ISSN 2078-8452

29. Socarrás A (1998) Mesofauna del suelo en pastizales antropizados. Magister Scientiae dissertation. La Habana

30. Sousa JP, da Gama MM, Pinto C, Keating A, Calhoa F, Lemos M, Castro C, Luz T, Leitao P, Dias S (2004) Effects of land-use on Collembola diversity patterns in a Mediterranean landscape. https:// doi.org/10.1016/j.pedobi.2004.06.004

Publisher's Note Springer Nature remains neutral with regard to jurisdictional claims in published maps and institutional affiliations. 